\title{
A Comparative Study of Eight Distinct $\beta$-Lactamases Synthesized by Gram-negative Bacteria
}

\author{
By G. W. JACK AND M. H. RICHMOND \\ Department of Bacteriology, University of Bristol, Bristol, BS8 ITD
}

(Accepted for publication 9 December 1969)

\begin{abstract}
SUMMARY
The enzymic properties of 46 strains of $\beta$-lactamase-producing enteric bacteria were examined. Eight distinct types of $\beta$-lactamase were detected among these strains when substrate profile, sensitivity to $p$-chloromercuribenzoate $(p \mathrm{CMB})$ and to cloxacillin inhibition, reaction with antiserum and charge properties are used as parameters of enzyme type. The types of enzyme detected ranged from molecules with a predominantly cephalosporinase profile to those where penicillins were hydrolysed much more rapidly than cephalosporins. The majority of isolates synthesized an enzyme that was almost equally active against penicillins and cephalosporins. To date only three of the eight types of enzyme have been shown to be transferable by conjugation.
\end{abstract}

\section{INTRODUCTION}

So far, three distinct types of $\beta$-lactamases (E.C. $3 \cdot 5 \cdot 2.6$ ) have been purified from Gram-negative bacterial species. These are the penicillinase synthesized by a strain of Escherichia coli carrying the R-factor $\mathrm{R}_{\mathrm{TEM}}$ (Datta \& Kontomichalou, 1965; Datta \& Richmond, I966), the cephalosporinase from Enterobacter cloacae strain 2I4 (Hennessey, 1967; Hennessey \& Richmond, 1968) and the enzyme from E. coli strain K I2 (Lindström, Boman \& Steele, I970). The enzyme from E. cloacae 214 is almost certainly identical to the enzyme partially purified from Aerobacter cloacae, strain P99, by Goldner, Glass \& Fleming (I968). In addition to this, there have been many reports over the last few years that describe the properties of $\beta$-lactamases synthesized by a wide range of Gram-negative organisms (e.g. Smith, 1963; Ayliffe, I965; Hamilton-Miller, I963, I967; see also reviews by Citri \& Pollock, I966; Evans, Galindo, Olarte \& Falkow, 1968; Sawai, Mitsuhashi \& Yamagishi, I968; HamiltonMiller, Smith \& Knox, 1969). In most cases these studies were made with crude enzyme preparations, or sometimes even on broken cell preparations, and classification was often based on only a narrow range of enzyme characters. Furthermore, where the substrate profile of an enzyme has been investigated, the results are often difficult to interpret since a wide range of different assay techniques has been used by different workers (using the iodometric, manometric and hydroxamate methods, or by bioassay), under various conditions of $\mathrm{pH}$ value and temperature. From this information (much of it conflicting) two facts do emerge clearly. First, certain enzymes may be inactivated irreversibly, as far as hydrolysis of ampicillin and benzylpenicillin are concerned at least, by pre-treatment with cloxacillin or methicillin (Hamilton-Miller, Smith \& Knox, 1965) in a manner reported earlier for staphylococcal penicillinase (Gourevitch, Pursiano \& Lein, I962). Secondly, some, but not all, $\beta$-lactamases from 
Gram-negative bacteria may be inhibited by treatment with $p$-chloromercuribenzoate $(p \mathrm{CMB})$ (Smith, 1963). This last observation implies that some $\beta$-lactamases from Gram-negative bacteria contain at least one cysteine residue. It is therefore difficult to be clear how many different types of $\beta$-lactamase are to be found among Gramnegative bacteria and what is their distribution among the various species.

In an attempt to clarify this, it was decided to examine the properties of the $\beta$ lactamases synthesized by a range of ampicillin-resistant Gram-negative strains (excluding pseudomonads) freshly isolated from a wide variety of sources. For this purpose each enzyme was isolated in crude form and characterized in terms of its substrate profile against benzylpenicillin, ampicillin and cephaloridine; and for its sensitivity to $p \mathrm{CMB}$ and to cloxacillin inhibition. In addition each enzyme was tested for its reaction with a rabbit antiserum prepared against purified $\beta$-lactamase from Escherichia coli carrying $\mathrm{R}_{\text {TEM }}$; where a positive result was obtained, the detailed kinetics of interaction were investigated further. A final test was to examine the electrophoretic mobility of partially purified preparations after electrophoresis in starch gel at $\mathrm{pH}$ 8.5. This last test also provides a check against the possibility that a single bacterial strain might be synthesizing two distinct lactamase proteins.

On the basis of these parameters, it has been possible to distinguish eight distinct types of $\beta$-lactamase among the strains examined here. The enzymes range from a molecule that is almost totally a 'cephalosporinase' in its substrate profile, to one that is almost entirely a 'penicillinase'. Other characteristics show that the strains may be grouped in other ways, the closest correlation being that all enzymes that were sensitive to $p \mathrm{CMB}$ were resistant to inhibition by cloxacillin. Only three of the eight types of enzyme examined here were mediated by genes carried on transmissible Rfactors present in the strains at the time of isolation.

\section{METHODS}

Strains and growth conditions. The $\beta$-lactamase producing organisms used in this work, and their origins are shown in Table $\mathrm{I}$. They were grown routinely in $0.1 \%$ CY medium (Novick, 1963) which has the following composition: sodium $\beta$-glycerophosphate, $0 . \mathrm{I} 2 \mathrm{M} ; \mathrm{MgSO}_{4} .5 \mathrm{H}_{2} \mathrm{O}, \mathrm{I} \cdot 0 \mathrm{mM}$; trace metal solution, $0.02 \mathrm{ml}$./1.; yeast extract (Oxoid), $\mathrm{I} \cdot 0 \%(\mathrm{w} / \mathrm{v})$; Casamino acids (Oxoid), $\mathrm{x} \cdot 0 \%$ (w/v); glucose, $0.4 \%(\mathrm{w} / \mathrm{v})$. The trace metal solution contained $(\%): \mathrm{CuSO}_{4} \cdot 5 \mathrm{H}_{2} \mathrm{O}, 0.5 ; \mathrm{ZnSO}_{4} \cdot 7 \mathrm{H}_{2} \mathrm{O}, 0.5$; $\mathrm{FeSO}_{4} \cdot 7 \mathrm{H}_{2} \mathrm{O}, 0.5 ; \mathrm{MnCl}_{2} \cdot 4 \mathrm{H}_{4} \mathrm{O}, 0.2$; conc. $\mathrm{HCl}$, Io $(\mathrm{v} / \mathrm{v})$. The glucose and $\beta$-glycerophosphate were sterilized separately and added just before use. Agar (I.5\%, w/v) was added to this medium when required. A mutant of Escherichia coli K I2 W3I Io that synthesized alkaline phosphatase at a fully derepressed rate in the presence of inorganic phosphate was used to detect $\mathrm{R}$-factor transfer. This strain was obtained as described by Lee \& Richmond (I969).

$\beta$-Lactamase assay. $\beta$-Lactamase activity was normally assayed iodometrically by the method of Perret (I954) as modified by Novick (1962) except that the assays were done at $\mathrm{pH} 5 \cdot 9$ rather than $\mathrm{pH} 7 \cdot 0$. The quantity of benzylpenicillin and ampicillin destroyed in this assay was calculated from the fact that each mole of hydrolysed benzylpenicillin reacted with eight equivalents of iodine (Alicino, 1946); the same equivalence was assumed for ampicillin. The hydrolysis of cephaloridine was followed similarly by assuming that $\mathrm{I}$ mole of cephaloridine reacted with four equivalents of iodine 
Table I. The sources and some characteristics of the $46 \beta$-lactamase-producing organisms used in these experiments

\begin{tabular}{|c|c|c|c|c|}
\hline & Strain & & & \\
\hline $\begin{array}{l}\text { Series } \\
\text { no. }\end{array}$ & $\begin{array}{l}\text { Source } \\
\text { no. }\end{array}$ & $\begin{array}{l}\text { Tentative } \\
\text { identification }\end{array}$ & Source & Reference (if any) \\
\hline $\mathbf{I}$ & TEM & E. coli $\left(\mathrm{R}_{\mathrm{TEM}}^{+}\right)$ & Dr N. Datta & $\begin{array}{l}\text { Datta \& } \\
\text { Kontomichalou (1965) }\end{array}$ \\
\hline 2 & 53 & Aerobacter cloacae & Dr J. T. Smith & Smith (I963) \\
\hline 3 & $48 \mathrm{I}$ & Klebsiella sp. & U.B.H. & - \\
\hline 4 & $24 \mathrm{I}$ & Aeromonas sp. & U.B.H. & - \\
\hline 5 & 418 & $K$. aerogenes & Dr J. M. T. Hamilton-Miller & Hamilton-Miller (1963) \\
\hline 6 & $07 \mathrm{I}$ & E. coli & $\mathrm{U}$ of $\mathrm{B}$ & - \\
\hline 7 & I 266 & Proteus morganii & U.B.H. & - \\
\hline 8 & D 539 & Klebsiella sp. & U.B.H. & - \\
\hline 9 & $2 / 37$ & Aeromonas sp. & U.B.H. & - \\
\hline 10 & $2 / 46$ & Aerobacter sp. & U.B.H. & - \\
\hline II & 8 & E. coli & $U$ of $B$ & - \\
\hline 12 & I8 & Aeromonas sp. & $U$ of $B$ & - \\
\hline 13 & $2 / 40 / \mathrm{I}$ & E. coli & U.B.H. & - \\
\hline I4 & $2 / 40 / 2$ & E. coli & U.B.H. & - \\
\hline I5 & $\mathrm{NPL}_{3}$ & E. coli & $\mathrm{U}$ of $\mathrm{B}$ & - \\
\hline I6 & $D_{31}$ & E. coli & Dr H. Boman & Lindström et al. (1970) \\
\hline 17 & D 535 & Klebsiella sp. & U.B.H. & - \\
\hline 18 & CJL & E. coli & $\mathrm{U}$ of $\mathrm{B}$ & - \\
\hline 19 & $1082 \mathrm{E}$ & Enterobacter cloacae & Dr C. O'Callaghan & - \\
\hline 20 & 466 & Klebsiella sp. & U.B.H. & - \\
\hline $2 I$ & 214 & Enterobacter cloacae & Dr T. Hennessey & Hennessey (1967) \\
\hline 22 & P 99 & Aerobacter cloacae & Dr T. Hennessey & Fleming et al. (1963) \\
\hline 23 & 284 & E. coli & U.B.H. & - \\
\hline 24 & I 390 & Aeromonas sp. & U.B.H. & - \\
\hline 25 & 1169 & Klebsiella sp. & U.B.H. & - \\
\hline 26 & 1758 & E. coli & U.B.H. & - \\
\hline 27 & 264 & Klebsiella sp. & U.B.H. & - \\
\hline 28 & D II44 & E. coli & U.B.H. & - \\
\hline 29 & 1316 & E. cloacae & U.B.H. & - \\
\hline 30 & 153 & E. cloacae & U.B.H. & - \\
\hline $3 I$ & 1929 & E. cloacae & U.B.H. & - \\
\hline 32 & 612 & Aerobacter sp. & U.B.H. & - \\
\hline 33 & 177 & Enterobacter cloacae & U.B.H. & - \\
\hline 34 & 719 & E. coli & U.B.H. & - \\
\hline 35 & 533 & Enterobacter cloacae & U.B.H. & - \\
\hline 36 & 3 II & Klebsiella sp. & U.B.H. & - \\
\hline 37 & 347 & Klebsiella sp. & U.B.H. & - \\
\hline 38 & 9527 & Klebsiella sp. & N.C.T.C. & - \\
\hline 39 & 115 & Klebsiella sp. & N.C.T.C. & - \\
\hline 40 & 3117 & Proteus vulgaris & U.B.H. & - \\
\hline $4 \mathrm{I}$ & 385 & Alkaligenes sp. & U.B.H. & - \\
\hline 42 & Denston 5003 & E. coli & A.H.C. & - \\
\hline 43 & McDonald & Klebsiella sp. & A.H.C. & - \\
\hline 44 & Shine & Klebsiella sp. & A.H.C. & - \\
\hline 45 & Wickham & E. coli & A.H.C. & - \\
\hline 46 & Robinson & Klebsiella $\mathrm{sp}$. & A.H.C. & - \\
\hline
\end{tabular}

Abbreviations: U.B.H., United Bristol Hospitals; U of B, University of Bristol, Department of Bacteriology; A.H.C., Addenbrookes Hospital, Cambridge; N.C.T.C., National Collection of Type Cultures.

All strains were identified according to the criteria of Cowan \& Steel (1966) except where reference is quoted. 
after hydrolysis as was found for cephalosporin (Alicino, I96I). Activities are expressed in units as defined by Pollock \& Torriani (I953).

For certain purposes the hydrolysis of cephaloridine was followed spectrophotometrically by measuring the decrease in absorption at $255 \mathrm{~nm}$. that accompanied the breaking of the $\beta$-lactam bond in this antibiotic. The advantage of this method is that it allows the hydrolysis of cephaloridine to be followed in mixtures containing benzylpenicillin, ampicillin or cloxacillin, since these compounds have no significant absorption at $255 \mathrm{~nm}$. For most purposes $3 \mathrm{ml}$. of a $100 \mu \mathrm{M}$ solution of cephaloridine was used for this assay. This amount of substrate had an initial extinction of about $\mathrm{I} \cdot 4$ at $255 \mathrm{~nm}$.

Substrate profiles. Substrate profiles were determined with benzylpenicillin, ampicillin and cephaloridine as substrates on crude preparations of enzyme. All these compounds were used at $6 \mathrm{~mm}$. The profiles were calculated against an arbitrary value of 100 for the rate of hydrolysis of benzylpencillin and are quoted in the form of three values separated by a colon. Thus a profile 100:150:175 indicates an enzyme that hydrolyses ampicillin at $\mathrm{I} \cdot 5$ times the rate, and cephaloridine at $\mathrm{I} \cdot 75$ times the rate, of benzylpenicillin.

Anti-TEM serum production. Penicillinase was purified from Escherichia coli $\left(R_{\mathrm{TEM}}\right)$ by the method of Datta \& Richmond (I966) and antiserum prepared against this enzyme essentially as described by Pollock (1964). The antigen was injected intramuscularly at 4-day intervals into alternate thigh muscles of rabbits as a suspension of $5 \mathrm{mg}$. enzyme $/ \mathrm{ml}$. Freund's adjuvant (Freund \& Bonanto, I94I). Initially $0 \cdot 2 \mathrm{ml}$. was injected, but subsequently the dose was increased to $0.5 \mathrm{ml} . ; 8.5 \mathrm{mg}$. in all was injected. After 2 weeks, injection in the marginal ear vein was recommenced at 2-day intervals with alum-precipitated enzyme preparation containing about $2.5 \mathrm{mg}$. antigen $/ \mathrm{ml}$.; in this case a total of $7.5 \mathrm{mg}$. of enzyme was injected. After a further I4 days, blood was taken from the rabbits and serum prepared by allowing the blood to clot for $2 \mathrm{hr}$ at room temperature, followed by standing overnight at $2^{\circ}$. The clot was then loosened and the liquid serum removed, the serum centrifuged at $1500 \mathrm{~g}$ for $30 \mathrm{~min}$. at $2^{\circ}$ in a refrigerated centrifuge and stored at $-20^{\circ}$.

Enzyme purifications. Enzyme preparations from Escherichia coli $\left(\mathrm{R}_{\mathrm{TEM}}\right)$ and Enterobacter cloacae strain 214 were purified by the methods described by Datta \& Richmond (I966) and Hennessey \& Richmond (I968), respectively. The first of these two enzymes is commonly referred to as TEM-enzyme or TEM-lactamase. Crude preparations of all other enzymes examined here were made as follows. An overnight culture of the organism in question, grown in liquid CY medium, was taken and samples ( $17 \mathrm{ml}$. at a time) were disrupted for $2.5 \mathrm{~min}$. at room temperature in a Mullard $25 \mathrm{kcyc}$./sec. ultrasonic disintegrator (Measuring and Scientific Instruments Ltd.). After breaking, the preparations were stored at $2^{\circ}$ until required for use. In certain cases where the amount of lactamase synthesized by the organisms was very small, the original culture was centrifuged at $5000 \mathrm{~g}$ for $\mathrm{I} 5 \mathrm{~min}$. and the pellet suspended at ten times the original suspension density in $0 . \mathrm{I}$ M-phosphate buffer $(\mathrm{pH}$ 5.9) before breaking.

Partially purified preparations of the enzymes studied here were prepared by one of two methods, depending on the ionization properties or the enzyme concerned. Both methods of preparation involved an initial disruption of the organisms in the ultrasonic disintegrator. For this an overnight culture grown in CHY medium and con- 
taining about $3 \mathrm{mg}$. dry wt organisms $/ \mathrm{ml}$. was centrifuged for $40 \mathrm{~min}$. at $15,000 \mathrm{~g}$. After centrifugation, the organisms were suspended to about $50 \mathrm{mg}$. dry wt $/ \mathrm{ml}$. in O.I M-phosphate buffer ( $\mathrm{pH} 5 \cdot 9$ ). This suspension was then disrupted as described above and the broken organisms stored at $2^{\circ}$ until breaking was complete. The broken organisms were then centrifuged at $30,000 \mathrm{~g}$ for $50 \mathrm{~min}$. at $2^{\circ}$ and the pellet discarded. The supernatant fluid obtained from the $30,000 \mathrm{~g}$ centrifugation was then dialysed overnight at $2^{\circ}$ against rooo times its volume of distilled water, centrifuged once more at $30,000 \mathrm{~g}$ for $50 \mathrm{~min}$. to remove debris that appeared on dialysis, and stored at $2^{\circ}$ until required for loading on to the appropriate substituted cellulose column.

Two types of substituted cellulose were used to obtain partially purified enzyme: carboxymethyl-cellulose (CM) and diethyl-amino-ethyl-cellulose (DEAE). Both were prepared for use in a similar manner, the only difference being that with $\mathrm{CM}$ the phosphate buffer used was at $\mathrm{pH} 5.9$, whereas with DEAE it was at $\mathrm{pH} 7 \cdot 0$. The substituted celluloses were suspended in $0 . \mathrm{I}$ M-phosphate buffer of appropriate $\mathrm{pH}$ value and the fines removed. The material was then poured as a column in phosphate buffer and washed with the appropriate buffer until the effluent had reached the $\mathrm{pH}$ value of the washing buffer. The column was prepared for use by washing with distilled water until no free phosphate was detected in the effluent. The columns used in these experiments were normally about $1.5 \mathrm{~cm}$. in diameter and 10 to $20 \mathrm{~cm}$. long; about $500 \mathrm{ml}$. distilled water was required to free them of unbound phosphate. Enzyme preparations were loaded on to these columns in a volume of 2 to $5 \mathrm{ml}$. and washed in with distilled water. Distilled water was then used to elute the column until the effluent contained no protein. This step normally required about $150 \mathrm{ml}$. water; during this step much protein and pigmented material, but less than $5 \%$ of the penicillinase, passed through the column. The enzymes were then eluted from the column with one of two eluting buffers, depending on the nature of the column. With DEAE-columns the eluting buffer was $0^{\circ} \mathrm{I}$ M-phosphate buffer $(\mathrm{pH} 7 \cdot 0)$; with $\mathrm{CM}$-columns the buffer was $0 \cdot 2 \mathrm{M}$-phosphate buffer $(\mathrm{pH} 5 \cdot 9)$. Elution of u.v. absorbing material was followed at $254 \mathrm{~nm}$. with a Uvicord I column monitor (LKB Instruments); $\beta$-lactamase in the samples was assayed iodometrically. Chromatography of the enzymes studied here was normally carried out at room temperature. The only exceptions were enzymes known to be sensitive to $p$ CMB since experience showed that these enzymes were more labile; in these cases purification was done at $2^{\circ}$.

Starch-gel electrophoresis. Starch blocks for electrophoresis were prepared in $0.03 \mathrm{M}-$ borate buffer ( $\mathrm{pH} \mathrm{8.5)}$ by the method of Smithies (1955). Semi-purified enzyme preparations to be examined were loaded into slots cut in the gel, about rooo units enzyme in $0.075 \mathrm{ml}$. being loaded into each slot. The gels were then run for $2.5 \mathrm{hr}$ with a potential difference of $300 \mathrm{~V}$, using two buffer vessels on each side of the gel joined by a bridge. The vessel carrying the electrode was filled with saturated $\mathrm{NaCl}$ solution and the vessel next to the gel with $0.3 \mathrm{M}$ borate buffer $(\mathrm{pH} \mathrm{8.5)}$. After completion of the run the gel was sliced into two portions: one was stained for the presence of protein with the amido-black method (Offord, I 969); the other was used to locate $\beta$-lactamase activity; this was achieved by spraying the gel with a solution of $30 \mathrm{mg}$. benzylpenicillin in a solution containing 0.0I6 M- $\mathrm{I}_{2}+0 . \mathrm{I} 2 \mathrm{M}-\mathrm{KI}+\mathrm{O} \cdot \mathrm{I}$ M-phosphate buffer $(\mathrm{pH} 5.9)$. The iodine in this reagent coloured the gel blue except where the lactamase converted benzylpenicillin to penicilloic acid, thus producing a colourless zone. In practice all the enzymes examined here (including those with a predominant activity against 
cephalosporins) hydrolysed benzylpenicillin sufficiently rapidly to give a positive test under these conditions. After staining, the position of the enzyme was measured on the gel, its mobility calculated and the value expressed as $\mathrm{cm} . / \mathrm{hr}$.

Antiserum assays. The effect of anti-TEM serum on purified TEM enzyme was studied iodometrically as described for the reaction between anti-penicillinase serum and purified penicillinase from Staphylococcus aureus (Richmond, I963). The standard curve obtained when increasing quantities of anti-TEM serum were added to a fixed quantity of TEM-lactamase (constant antigen titration) is shown in Fig. I. The neutralization titre of the serum (used at $\mathrm{r} / \mathrm{IO}$ dilution in physiological saline) used in these experiments was 17 units/0.0I $\mathrm{ml}$. serum; the maximum degree of neutralizaation of the TEM-enzyme was approx. $60 \%$ at the equivalence point ( $E$, Fig. I).

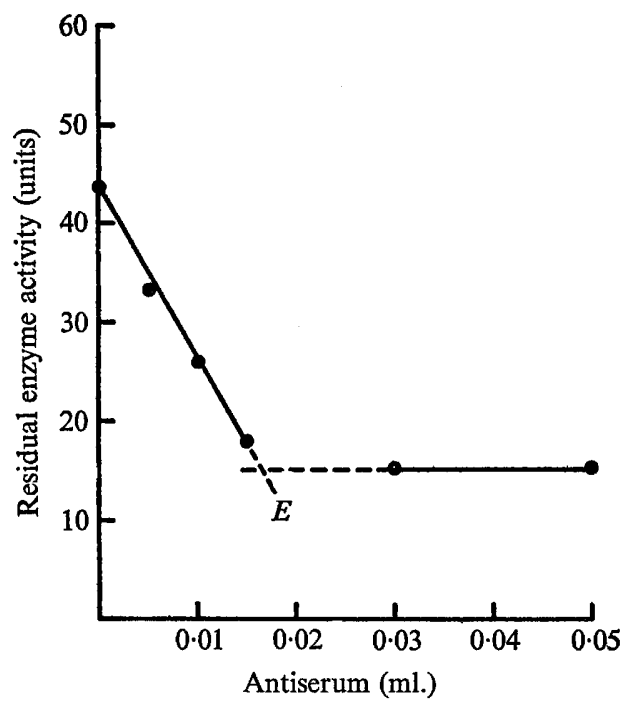

Fig. I. Neutralization curve obtained when TEM- $\beta$-lactamase was titrated with anti-TEM serum (constant antigen titration). $E$ : equivalence point.

Preparations of $\beta$-lactamase for test were compared with TEM-enzyme by measuring the degree of neutralization obtained with a test quantity of serum. Usually about 50 units enzyme were used in the test and the control assay and the effect of either 0.03 or $0.05 \mathrm{ml}$. serum determined. These conditions were chosen to give complete neutralization of the 50 units of enzyme used. Only when the effect of the serum on the test enzyme under these conditions was markedly different from that obtained with TEM-enzyme was the reaction between serum and TEM-enzyme examined in greater detail. Although unsatisfactory, this procedure was necessary to conserve serum.

Sensistivity to $p C M B$. Crude enzyme preparations were mixed with $p \mathrm{CMB}$ solutions to give a final concentration of $0.5 \mathrm{~mm}$ and the mixture incubated at $30^{\circ}$ for ro min. The residual enzyme activity was then estimated iodometrically. An enzyme sample incubated in absence of inhibitor acted as control. Sensitive enzyme preparations were inhibited by more than $80 \%$ by this treatment.

Sensitivity to cloxacillin. The sensitivity of the enzymes to cloxacillin was measured 
by using cephaloridine as substrate since the spectrophotometric method of assaying cephalosporins allowed the hydrolytic activity of the enzyme to be followed against this substrate even when another potentially sensitive $\beta$-lactam compound was present in solution. A solution containing $\mathrm{IO}^{-4} \mathrm{M}$-cloxacillin and $\mathrm{IO}^{-4} \mathrm{M}$-cephaloridine in $\mathrm{O} \cdot \mathrm{I} \mathrm{M}$ phosphate buffer $(\mathrm{pH} 7 \cdot 0$ ) was incubated for $5 \mathrm{~min}$. in a cuvette in a continuously recording spectrophotometer and the spontaneous breakdown of the cephaloridine component of the mixture followed. A second cuvette containing cephaloridine alone in O.I M buffer was incubated in parallel to give the control rate. At the end of this period about 50 units enzyme were added to each cuvette and the hydrolysis of cephaloridine followed for a further $15 \mathrm{~min}$. The degree of inhibition caused by the presence of the cloxacillin was then calculated by comparing the initial rate of hydrolysis of cephaloridine in the two cuvettes. A 'resistant' enzyme was defined as one that retained more than $65 \%$ of its activity in the presence of cloxacillin. All 'sensitive' enzymes in this series showed less than $25 \%$ of their normal activity in the presence of the inhibitor. It must be stressed both in the case of cloxacillin and $p$ CMB-inhibition that 'sensitivity' of the enzymes was always more significant than 'resistance', since the assays were made with crude enzyme preparations and 'resistance' could be due to the presence of compounds that inactivated the inhibitors.

Transferability of $\beta$-lactamase genes. The transferability by conjugation of the genes concerned with $\beta$-lactamase synthesis in these strains was determined by mating experiments in which the potential donor culture was mixed with a standard recipient strain (Lee \& Richmond, 1969). The recipient used was a mutant of Escherichia coli K I2 W 3 I Io that was sensitive to ampicillin and that synthesized alkaline phosphatase at a fully de-repressed rate even when grown on media containing high concentrations of inorganic phosphate. The advantage of this recipient is that it is easy to identify by staining the colonies for the presence of alkaline phosphatase. The test was done by mixing exponentially growing cultures (about $10^{6}$ bacteria/ml.) in the ratio of $\mathrm{I}$ volume donor culture to Io volumes recipient. The mixture was incubated at $35^{\circ}$ in stationary culture, and after overnight growth the organisms were plated on agar containing $25 \mu \mathrm{g}$. ampicillin/ml. Any ampicillin-resistant colonies that grew on these plates were derived either from the donors or from recipients that had received the $\beta$-lactamase gene from the donor, since transfer of the alkaline phosphatase genes in the opposite direction (i.e. from recipient to donor) did not occur at a detectable rate with the recipient strain used here (Lee \& Richmond, 1969). The recipient colonies that had received $\beta$-lactamase were distinguished from donor colonies by staining for the presence of alkaline phosphatase with a mixture of $\alpha$-naphthyl-phosphate and 3,3'-dimethoxybenzidine (Fast Blue B salt; G. T. Gurr Ltd., London; Menten, Junge \& Green, 1944) as described by Lee \& Richmond (1969). The presence of about 5 colonies/plate in which $\beta$-lactamase synthesis was associated with production of alkaline phosphatase was taken to denote the presence of a transferable lactamase gene in the donor.

Buffers. All phosphate buffers were $\mathrm{K}_{2} \mathrm{HPO}_{4}+\mathrm{KH}_{2} \mathrm{PO}_{4}$ mixtures. 


\section{RESULTS}

Substrate profile and total amount of protein synthesized

The enzymes from 43 strains were examined for their substrate profiles as described in Methods; the results plotted in Fig. 2. In addition enzymes from Escherichia coli $\left(\mathrm{R}_{\mathrm{TEM}}\right)$, Aerobacter cloacae strain $\mathrm{P} 99$ and Enterobacter cloacae strain 2I4 were examined in the same way and the results also plotted. These preliminary results showed four broad types of substrate profile: group I (including enzyme from $E$. coli $\left(\mathrm{R}_{\mathrm{TEM}}\right)$ and the majority of the other strains tested) had a profile

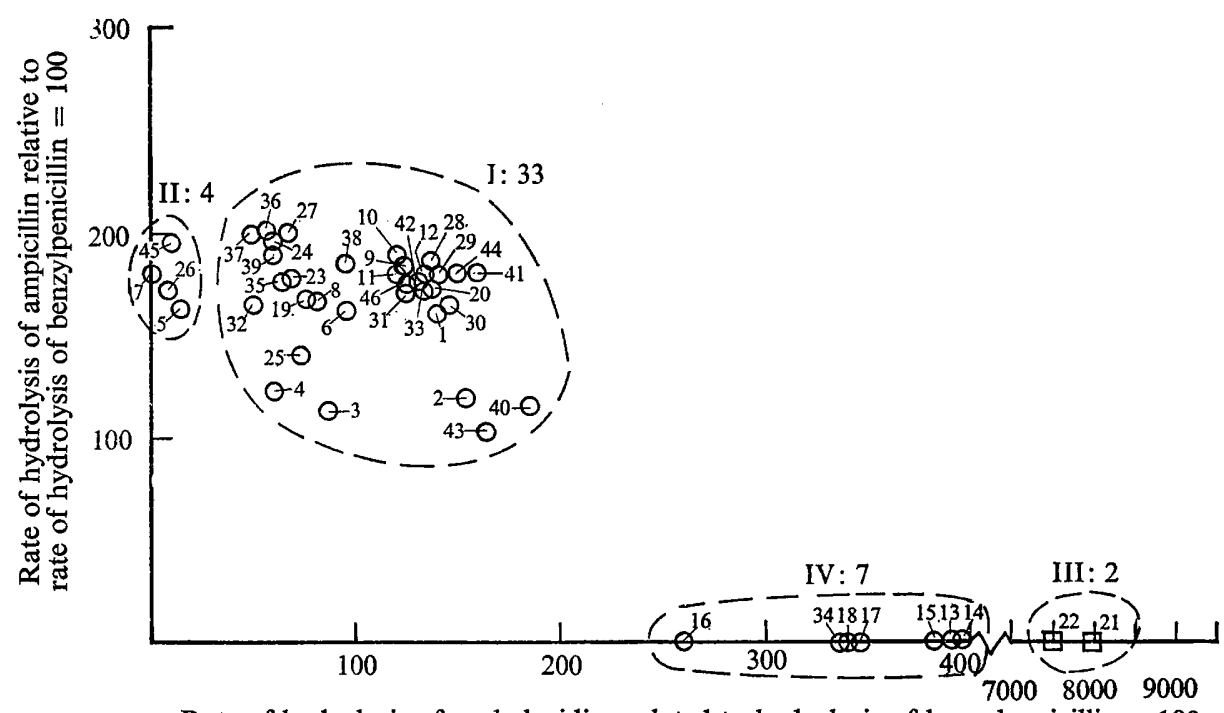

Rate of hydrolysis of cephaloridine related to hydrolysis of benzylpenicillin $=100$

Fig. 2. Substrate profiles of the $46 \beta$-lactamase synthesizing strains examined. The origin of the graph indicates a value for the rate of benzylpenicillin hydrolysis $=100$. The numbers appended to each small circle refer to the identification numbers of the strains in the series (see Table I). The dashed circles enclose strains grouped to show the broad enzyme types (I, II, III, IV) described in the text. The large figures next to the roman numerals indicate the number of strains in the group in question. $O$, Strains plotted on the basic scale; $\square$, strains plotted on abscissa with scale 12.5 times smaller.

I00: I20-200:80-I50; group II had a profile I00:I80:0-I5; group III (containing only the enzymes from $A$. cloacae, strain P 99 and $E$. cloacae strain 214) had a profile I00: < I0:8000; group IV had a profile I00: < I0:350. Each of these groups is outlined with a dotted line in Fig. 2. The number of strains in each group is also shown in Fig. 2.

Calculation of the specific $\beta$-lactamase activity (enzyme units determined with benzylpenicillin as substrate/mg. dry wt organism) of these strains gave the results shown in Table 2 . When an arbitrary division is set at a specific activity of Io enzyme units/mg. dry wt and these results are correlated with substrate profile, an almost complete division of group I into two subgroups can be seen (Fig. 3): almost all strains with a specific activity greater than the limiting value lie on the right-hand side of the group round an average profile of 100: $120-200: 150$, while strains express- 


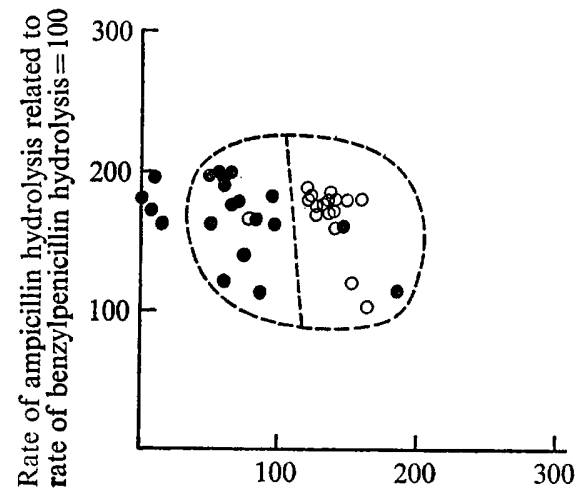

Rate of cephaloridine hydrolysis related to hydrolysis of benzylpenicillin $=100$

Fig. 3. Fig. 2 replotted to show the strains that synthesize $\beta$-lactamase at a rate less than Io units/mg. dry wt organisms with benzylpenicillin $(\bullet)$, and those where enzyme synthesis exceeds this limit $(O)$. The origin of the graph indicates a ratio of benzylpenicillin hydrolysis $=100$. This method of plotting is inappropriate for strains where the rate of cephaloridine hydrolysis greatly exceeds that of benzylpenicillin, and these cases are omitted from the figure (cf. Fig. 2).

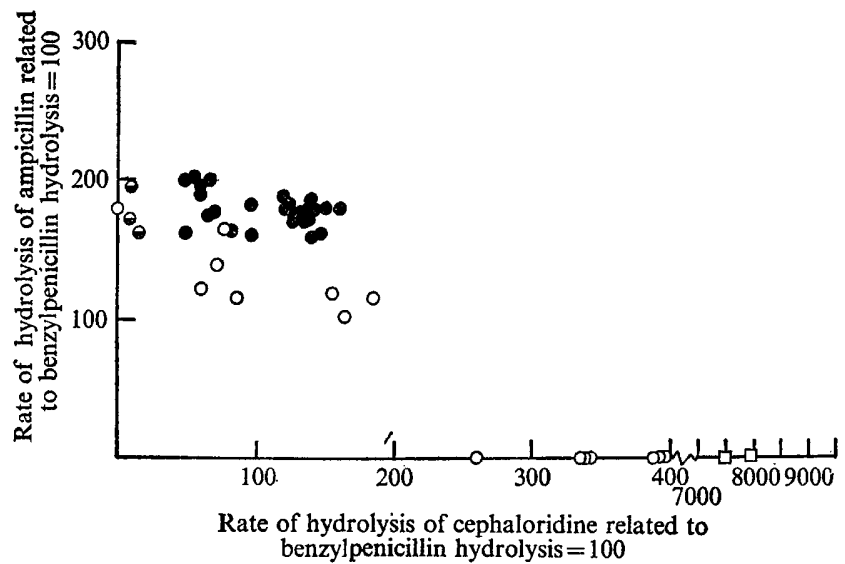

Fig. 4

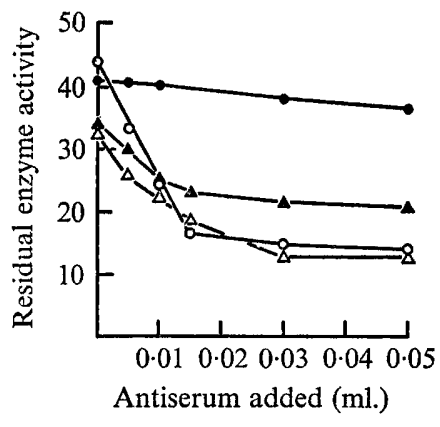

Fig. 5

Fig. 4. Fig. 2 replotted to show the strains in the series that cross-react with anti-TEM serum. Neutralization identical to TEM-enzyme; $\ominus$, some neutralization but different from the TEM-enzyme/anti-TEM serum reaction; $\bigcirc$, no neutralization.

Fig. 5. The neutralization curves obtained when the reaction between anti-TEM serum and the $\beta$-lactamases from strain 1758,418 and Wickham were compared with the neutralization of TEM-enzyme with anti-TEM serum. $O$, TEM-enzyme/anti-TEM serum; - I758-enzyme/anti-TEM serum; $\Delta, 4$ 18-enzyme/anti-TEM serum; and $\triangle$, Wickham/ anti-TEM serum. 
ing their enzyme below the limit mainly lie to the left-hand side of the group with an average profile of about 100: 120-200:90.

This division of group I into two subgroups suggested that there might be two distinct types of enzyme present. However, the difference in average profile between the

Table 2. Specific enzyme activities (enzyme units/mg. dry wt organisms with benzylpenicillin as substrate) for the $46 \beta$-lactamase producing strains examined here

\begin{tabular}{|c|c|c|}
\hline \multicolumn{2}{|c|}{ Strain } & \multirow[b]{2}{*}{$\begin{array}{l}\text { Specific } \\
\text { activity }\end{array}$} \\
\hline $\begin{array}{c}\text { Series } \\
\text { no. }\end{array}$ & $\begin{array}{c}\text { Source } \\
\text { designation }\end{array}$ & \\
\hline I & TEM & 55 \\
\hline 2 & 53 & 160 \\
\hline 3 & $48 \mathrm{I}$ & $\mathrm{I} \cdot 7$ \\
\hline 4 & $24 \mathrm{I}$ & $I \cdot I$ \\
\hline 5 & 418 & $I \cdot O$ \\
\hline 6 & 071 & 5 \\
\hline $\begin{array}{l}7 \\
8\end{array}$ & $\begin{array}{l}\text { I } 266 \\
\text { D } 539\end{array}$ & $\begin{array}{l}2 \cdot 2 \\
6 \cdot I\end{array}$ \\
\hline 9 & $2 / 37$ & I3 \\
\hline IO & $2 / 46$ & 48 \\
\hline I I & 8 & 65 \\
\hline 12 & I 8 & 30 \\
\hline 13 & $2 / 40 / I$ & $\mathrm{I} \cdot 2$ \\
\hline 14 & $2 / 40 / 2$ & $2 \cdot 4$ \\
\hline 15 & $D_{31}$ & 3.0 \\
\hline 16 & D 535 & $5 \cdot 2$ \\
\hline 17 & $\mathrm{NPL}_{3}$ & 16.4 \\
\hline I 8 & CJL & $2 \cdot 0$ \\
\hline 19 & $1082 \mathrm{E}$ & 76 \\
\hline 20 & 466 & 25 \\
\hline $2 \mathrm{I}$ & 214 & 0.9 \\
\hline 22 & P 99 & I 8 \\
\hline 23 & 284 & $\mathrm{I} \cdot 2$ \\
\hline
\end{tabular}

\begin{tabular}{|c|c|c|}
\hline \multicolumn{2}{|c|}{ Strain } & \multirow[b]{2}{*}{$\begin{array}{l}\text { Specific } \\
\text { activity }\end{array}$} \\
\hline $\begin{array}{c}\text { Series } \\
\text { no. }\end{array}$ & $\begin{array}{c}\text { Source } \\
\text { designation }\end{array}$ & \\
\hline 24 & 1390 & $r \cdot O$ \\
\hline 25 & I I 69 & $2 \cdot I$ \\
\hline 26 & 1758 & $6 \cdot I$ \\
\hline 27 & 264 & I. O \\
\hline 28 & I I 44 & IIO \\
\hline 29 & 1316 & I4 \\
\hline 30 & I 53 & $4 \cdot 3$ \\
\hline $3 \mathrm{I}$ & 1929 & 17 \\
\hline 32 & 612 & I.5 \\
\hline 33 & 177 & $17 \cdot 3$ \\
\hline 34 & 719 & 20 \\
\hline 35 & 533 & $I \cdot 0$ \\
\hline 36 & 311 & $1 \cdot 6$ \\
\hline 37 & 347 & $I \cdot 3$ \\
\hline 38 & 9527 & $I \cdot 2$ \\
\hline 39 & I 15 & $\mathbf{I} \cdot \mathbf{O}$ \\
\hline 40 & 3117 & 0.9 \\
\hline $4^{\mathrm{I}}$ & 385 & 50 \\
\hline 42 & Denston 5003 & 86 \\
\hline 43 & McDonald & 350 \\
\hline 44 & Shine & 127 \\
\hline 45 & Wickham & 5 \\
\hline 46 & Robinson & I8 \\
\hline
\end{tabular}

Table 3. Substrate profiles of crude and semi-purified preparations from strain TEM (no. I, Table I) and o7I (no. 6, Table I)

\begin{tabular}{|c|c|c|c|c|c|}
\hline \multirow[b]{2}{*}{$\begin{array}{c}\text { Strain } \\
\text { designation }\end{array}$} & \multirow[b]{2}{*}{$\begin{array}{l}\text { Strain no. } \\
\text { (Table I) }\end{array}$} & \multirow{2}{*}{$\begin{array}{l}\text { Approximate } \\
\text { specific enzyme } \\
\text { activity } \\
\text { (enzyme } \\
\text { units } / \mu \mathrm{g} . \\
\text { protein) }\end{array}$} & \multicolumn{3}{|c|}{ Substrate profile } \\
\hline & & & $\begin{array}{l}\text { Benzyl- } \\
\text { penicillin }\end{array}$ & Ampicillin & Cephaloridine \\
\hline TEM & $\mathbf{I}$ & $0.1 \mathbf{I}$ & 100 & 160 & 140 \\
\hline TEM & I & Io & 100 & 165 & 135 \\
\hline 071 & 6 & 0.015 & IOO & 165 & 95 \\
\hline 071 & 6 & 2 & 100 & 165 & 135 \\
\hline
\end{tabular}

The specific enzyme activity of pure TEM- $\beta$-lactamase is 80 units/ $\mu$ g. protein (Datta \& Richmond, I966).

two subgroups was found to be due to a discrepancy introduced into the iodometric assay of cephalosporinase (but not of penicillinase) by the presence of large amounts of contaminating protein. The effect of this contamination can be seen by comparing the substrate profiles of crude and semi-purified enzyme preparations from strain 
TEM (synthesized at 55 units/mg. dry wt organisms, see Table 2) and strain 07 I (synthesized at 5 units/mg. dry wt, see Table 2). Partial purification of the TEM- $\beta$ lactamase had little effect on its substrate profile measured iodometrically (Table 3 ) but in the case of enzyme from strain $07 \mathrm{r}$, partial purification lead to a change in profile from I00: $165: 95$ in the crude material to I00: $165: 135$ after some purification (Table 3).

In summary, therefore, the division of group I into two subgroups probably reflected an imperfection in the assay procedure rather than a fundamental difference in type of enzyme, at least according to the characters determined so far. Subsequent work (described below) showed that there were indeed several different types of enzyme among the strains of group I but they were not distributed within the group as implied by the correlations shown in Fig. 3.

\section{Sensitivity of $\beta$-lactamases to anti-TEM serum}

Samples of crude enzyme from each strain were tested for sensitivity to neutralization by anti-TEM serum; Fig. 4 shows Fig. 2 replotted to denote which of the strains reacted with serum. In all, enzyme from 29 of the strains was neutralized to some extent and two types of response were obtained. In the majority of cases (26/29) the kinetics of neutralization were indistinguishable from those obtained with purified TEM enzyme and anti-TEM serum; but in three cases a shallower and less complete neutralization was obtained (Fig. 5). These three strains (I758, Wickham, 4I8) all synthesized enzyme with profile I00:150:0-I5; their detailed properties will be discussed below. All the strains with neutralization kinetics indistinguishable from the standard TEM/anti-TEM interaction lay in group I, but seven of the strains in this group did not react with anti-TEM serum at all (Fig. 4). Furthermore, these seven strains all lie together towards the bottom of the area occupied by group I in Fig. 2 and 4, suggesting that two fundamentally distinct types of enzyme are found in group I: one with profile of about 100:180:I50 that reacts with anti-TEM serum and the other with profile about I00:I I0: I50 distinguished by its insensitivity to antiserum. In general, no strain with an enzyme of predominantly cephalosporinase profile crossreacted with anti-TEM serum.

Sensitivity to $p C M B$. Samples of crude enzyme obtained from the test strains were examined for their sensitivity to $p$ CMB as described in Methods; Fig. 6 shows Fig. 2 replotted to show the enzymes susceptible to this inhibitor. Seven strains that synthesized $p$ CMB-sensitive enzyme were found; they were identical with the seven members of group I that did not react with anti-TEM serum (compare Fig. 4 and 6). These results confirmed, therefore, that group I contained at least two distinct types of $\beta$-lactamase: one reacting with anti-TEM serum, resistant to $p \mathrm{CMB}$ and with a profile of I00:180:90 to 180 ; and the other resistant to anti-TEM serum, sensitive to $p C M B$ and with a profile I00: $110: 90-180$ (compare Fig. 2, 4, 6).

As was the case with the TEM-like enzymes in group I, the seven strains synthesizing $p$ CMB-sensitive enzymes in this group also seemed to be in two subclasses: four forming one subclass with an average profile 100:100:170 and the other three with an average profile 100:100:80. However, unlike the TEM-like enzymes in group I, partial purification of these strains produced no significant change in substrate profile. On the basis of the results obtained so far, therefore, it is only possible to divide the strains in group I into two subgroups: 26 enzymes that react with anti- 
TEM serum and are resistant to $p \mathrm{CMB}$, and seven enzymes with the opposite properties. No subdivision of groups II, III and IV is possible on the basis of sensitivities to $p \mathrm{CMB}$.

Sensitivity to cloxacillin. Fig. 7 shows Fig. 2 replotted to denote which of the enzymes were sensitive to cloxacillin by the criteria set out in Methods. No enzymes from group II (Fig. 2) could be tested in this way because of their extremely feeble activity against cephaloridine. The clearest correlation to emerge from these measurements is that

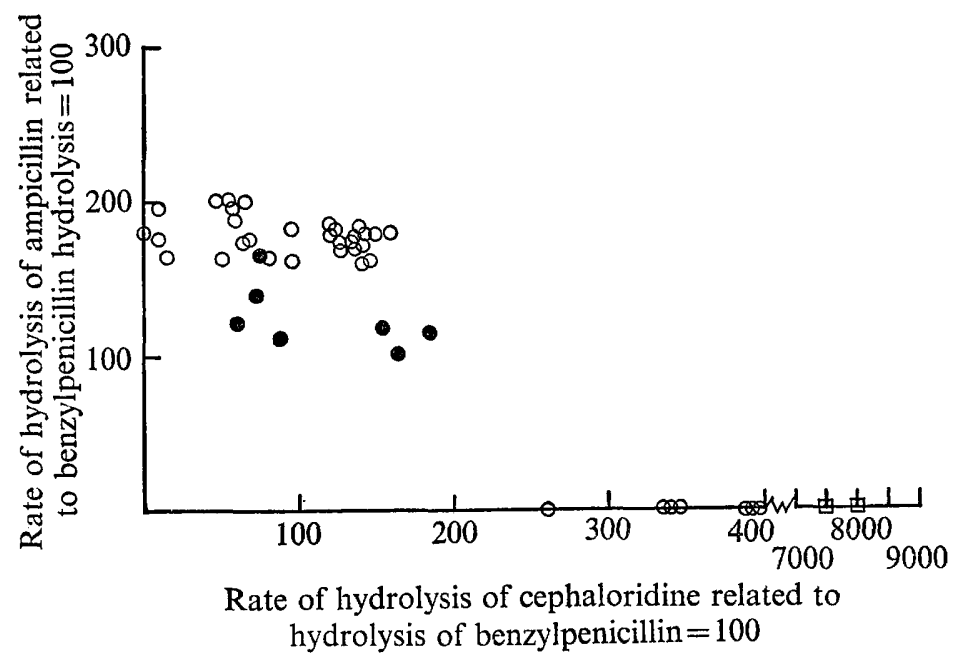

Fig. 6. Fig. 2 replotted to show the strains that synthesize $\beta$-lactamases sensitive to inhibition to $5 \times 10^{-3}$ M $p$ CMB. Strains synthesizing sensitive enzyme; $O$, resistant enzyme.

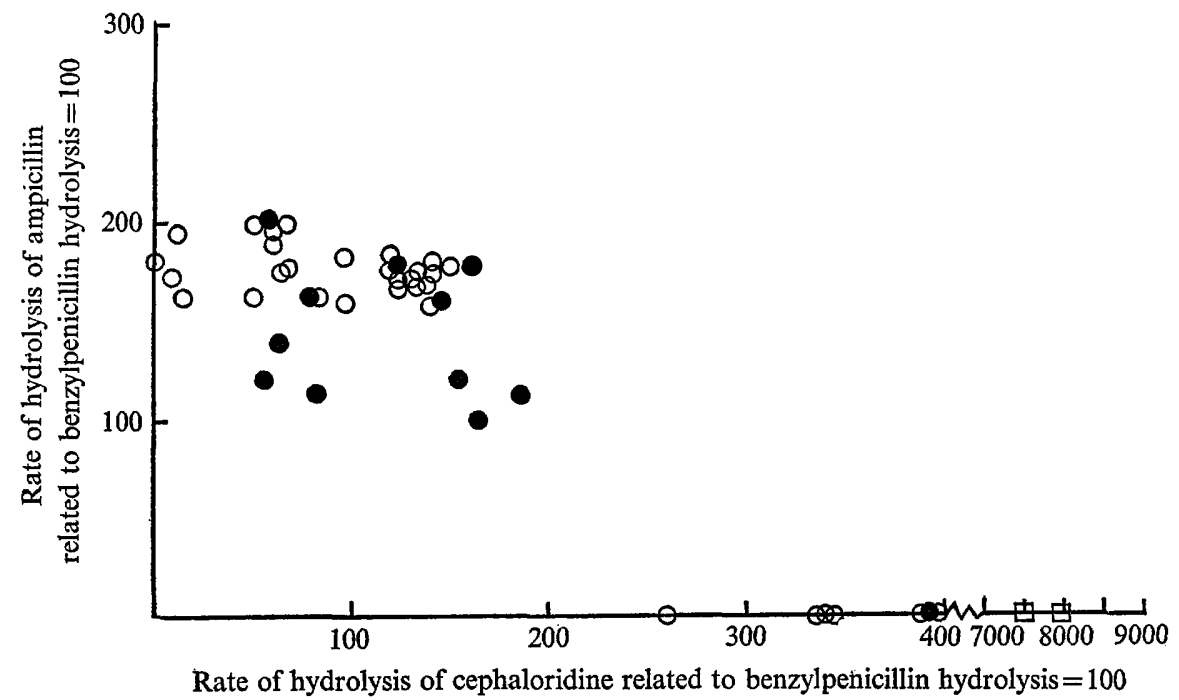

Fig. 7. Fig. 2 replotted to show the strains that synthesize $\beta$-lactamase sensitive to cloxacillin inhibition. $\bigcirc$, Sensitive enzymes; $\boldsymbol{O}$, resistant enzymes. 
all the enzymes sensitive to $p$ CMB (see Fig. 5) were resistant to cloxacillin. In addition, two other strains (nos. 30, 4I, Table I) were resistant to this inhibitor; this situation is discussed further below.

Absorption to substituted celluloses and electrophoretic mobility. Two procedures were used to obtain partially purified preparations of the enzymes-one involving the use of CM-cellulose and the other DEAE-cellulose (see Methods). In all cases crude enzyme preparations from the strains tested adsorbed either to one or the other of these celluloses but not to both. Table 4 shows the type of substituted cellulose

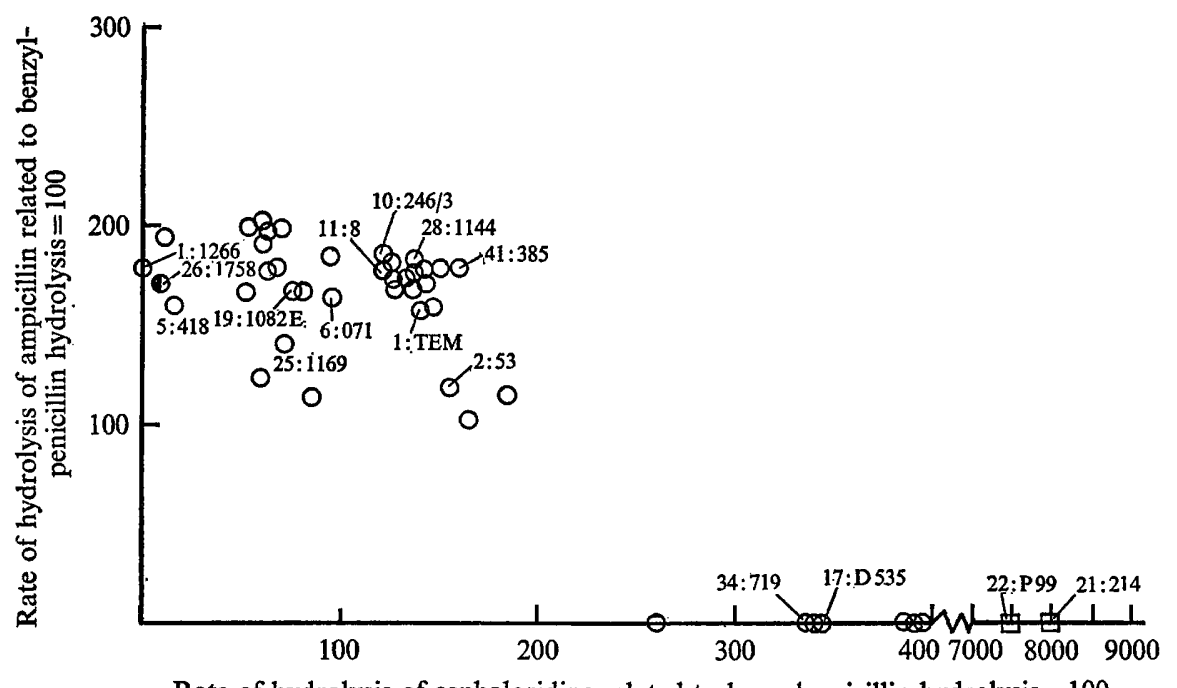

Rate of hydrolysis of cephaloridine related to benzylpenicillin hydrolysis $=100$

Fig. 8. The location, on a plot of the type used in Fig. 2, of the strains used to purify enzyme for mobility tests in starch gel. The numerals on the graph refer to the series numbers shown in Table I. O, Strain 1758 (which makes two enzymes).

used for purification of the enzymes studied. Although the adsorption characteristics of the enzymes gave some general idea of their charge properties, it was decided to separate the semi-purified enzymes by starch-gel electrophoresis at $\mathrm{pH} 8.5$ to obtain a detailed comparison of their mobility and thus some idea of their degree of ionization at that $\mathrm{pH}$ value. Starch-gel electrophoresis was done on partially purified enzymes as described in Methods but, in view of the large number of strains involved in these studies, it was decided to test only a selection from each enzyme group. The relative mobilities of these preparations, together with the strains from which they were derived, are shown in Table 4. In all, I5 strains were chosen; six from group I and the others to include as many representatives of the other groups as possible (see Fig. 8). Six types of mobility were detected. In one case, mobility was towards the cathode (at $+0.75 \mathrm{~cm} . / \mathrm{hr}$ ) and in three towards the anode $(-\mathrm{I} \cdot 6,-\mathrm{I} \cdot \mathrm{I},-0.6 \mathrm{~cm} . / \mathrm{hr})$. With two types of enzyme there was very little mobility at this $\mathrm{pH}$ value, but the enzymes could be distinguished because one moved slightly towards the cathode $(\sim+0 \cdot \mathrm{I}$ $\mathrm{cm}$. $/ \mathrm{hr}$ ) and the other at about the same rate towards the anode. On the basis of mobility alone, therefore, six types of enzyme were distinguished, but when these results were correlated with substrate profile the number of distinct enzyme types rose to eight. Two types of enzyme were present among those migrating with a low positive 
mobility at $\mathrm{pH} 8.5$. One of them (no. 2, Table I) had a profile 100:120:155, while nos. 2 I and 22 (Table I) had profiles 100:0:8000. Similarly, two types of enzyme migrated with a mobility of $-0.6 \mathrm{~cm} . / \mathrm{hr}$; no. I9 (Table I) had a profile I00: $170: 75$ while no. 7 had a profile $100: 180: 0$.

One of the strains tested by starch-gel electrophoresis (strain I758, no. 26, Table I) synthesized two distinct types of $\beta$-lactamase. This discovery immediately invalidated the use of substrate profile to characterize this strain since it was not certain how much of the activity against each substrate was contributed by each component enzyme. Fortunately one of the two enzymes in this strain was found to be carried on an Rfactor and this provided a means of studying the properties of each component enzyme uncontaminated by the other. The enzyme mediated by the R-factor gene was examined by transferring it to a strain that lacked $\beta$-lactamase. The enzyme transferred in this way was found to have a profile $100: 180: 0$, to be insensitive to anti-TEM serum, resistant to $p \mathrm{CMB}$ and sensitive to cloxacillin. The other enzyme was examined by obtaining an $R^{-}$variant of strain 1758 . This variant now synthesized only one type of enzyme with profile 100: $150: 160$, sensitive to anti-TEM serum, resistant to $p C M B$ and sensitive to cloxacillin; and in all ways this component was indistinguishable from TEM- $\beta$-lactamase.

The over-all substrate profile of strain 1758 (100: 170:10) allowed one to infer that the strain as originally isolated synthesized ten times as much enzyme with profile I00: I80:0 as it did TEM-lactamase. This mixture is also consistent with the intermediate type of response obtained when the mixed enzymes from this strain were tested for their interaction with anti-TEM serum (see p. $5 \mathrm{I}$ ). The other strains that showed an intermediate response to anti-TEM serum were strains 5 and 45 (Table I) (approx. profile I00:170:15). Electrophoretic studies gave no indication of inhomogeneity in the enzymes synthesized by these strains and it seems likely that this enzyme is indeed a distinct type of $\beta$-lactamase with a heterologous reaction with anti-TEM serum.

Transferability of $\beta$-lactamase genes. Twelve of the 46 strains examined here were capable of transferring their $\beta$-lactamase genes when grown overnight with the standard recipient strain (see Methods). Ten of the strains shown to have transferable genes by this test synthesized TEM-like enzyme, one synthesized enzyme with profile 100:0:400 and (as described above) one enzyme from strain $175^{8}$ (the one with profile roo: $180: 0$ ) could be transferred by cell-to-cell contact. No transfer of the enzyme from either Enterobacter cloacae strain 2I4 or Aerobacter cloacae strain P 99 have ever been reported and it seems likely that the gene specifying this type of $\beta$-lactamase is chromosomal. Too little is yet known about the transfer properties of the strains that did not transfer the lactamase genes in this test to be dogmatic about their genetic constitution.

\section{DISCUSSION}

At least eight different types of $\beta$-lactamase can be detected among the enteric bacteria on the basis of the parameters used here; the characteristics of these enzymes are summarized in Table 5. They may be classified in a number of ways depending on the properties chosen for correlation. Enzyme types 2 and 5 (Table 5), for example, are predominantly cephalosporinases while types 6 and 7 are mainly penicillinases. All the remaining enzymes examined here hydrolyse the three substrates at a significant 
Table 4. Electrophoretic mobility and adsorption characteristics of partially purified enzyme preparations from a number of strains

\begin{tabular}{|c|c|c|c|}
\hline \multicolumn{2}{|c|}{ Strains } & \multirow{2}{*}{$\begin{array}{l}\text { Chromoto- } \\
\text { graphed on }\end{array}$} & \multirow{2}{*}{$\begin{array}{l}\text { Mobility } \\
(\mathrm{cm} . / \mathrm{hr})\end{array}$} \\
\hline Series no. & Source no. & & \\
\hline I & TEM & DEAE & $-I \cdot 6$ \\
\hline 2 & 53 & $\mathrm{CM}$ & $+0 . I$ \\
\hline 5 & 418 & DEAE & $-0 . I$ \\
\hline 6 & $07 \mathrm{I}$ & DEAE & $-I \cdot 6$ \\
\hline 7 & I 266 & DEAE & -0.6 \\
\hline Io & $246 / 3$ & DEAE & $-1 \cdot 6$ \\
\hline II & 8 & DEAE & $-I \cdot 6$ \\
\hline I7 & D 535 & $\mathrm{CM}$ & +0.7 \\
\hline 19 & $1082 \mathrm{E}$ & DEAE & -0.6 \\
\hline $2 \mathrm{I}$ & 214 & $\mathrm{CM}$ & +0.1 \\
\hline 22 & P 99 & CM & $+0 . x$ \\
\hline 25 & 1169 & DEAE & $-I \cdot I$ \\
\hline 28 & I I 44 & DEAE & $-I \cdot 6$ \\
\hline 34 & 719 & $\mathrm{CM}$ & +0.7 \\
\hline $4 \mathrm{I}$ & 385 & DEAE & $-I \cdot 6$ \\
\hline
\end{tabular}

Abbreviations: $\mathrm{CM}=$ Carboxymethyl cellulose; $\mathrm{DEAE}=$ diethyl-aminoethyl-cellulose; $+=$ mobility towards cathode $;-=$ mobility towards anode.

Table 5. Properties of the eight types of $\beta$-lactamase detected among the enteric bacteria

\begin{tabular}{|c|c|c|c|c|c|c|c|c|c|}
\hline \multirow[b]{3}{*}{$\begin{array}{c}\text { Enzym } \\
\text { type }\end{array}$} & \multirow[b]{3}{*}{$\begin{array}{l}\text { Type species } \\
\text { (if any) }\end{array}$} & \multirow{2}{*}{\multicolumn{3}{|c|}{$\begin{array}{c}\text { Substrate profile } \\
\text { (hydrolysis of } \\
\text { benzylpenicillin = IOO) }\end{array}$}} & \multicolumn{3}{|c|}{ Sensitivity to } & \multirow[b]{3}{*}{$\begin{array}{l}\text { Chromato- } \\
\text { graphed on }\end{array}$} & \multirow[b]{3}{*}{$\begin{array}{l}\text { Mobility } \\
(\mathrm{cm} . / \mathrm{hr})\end{array}$} \\
\hline & & & & & \multirow{2}{*}{$\begin{array}{l}\text { Anti- } \\
\text { TEM } \\
\text { serum }\end{array}$} & \multirow[b]{2}{*}{$p \mathrm{CMB}$} & \multirow[b]{2}{*}{$\begin{array}{l}\text { Cloxa- } \\
\text { cillin }\end{array}$} & & \\
\hline & & $\begin{array}{l}\text { Benzyl- } \\
\text { penicillin }\end{array}$ & $\begin{array}{l}\text { Ampi- } \\
\text { cillin }\end{array}$ & $\begin{array}{l}\text { Cepha- } \\
\text { loridine }\end{array}$ & & & & & \\
\hline $\mathbf{I}$ & E. coli TEM & 100 & 150 & 180 & + & $\mathbf{R}$ & $\mathbf{S}$ & DEAE & $-I \cdot 6$ \\
\hline 2 & $\begin{array}{l}\text { Aerobacter } \\
\text { cloacae } \mathrm{P}_{99}\end{array}$ & 100 & 0 & 8000 & - & $\mathbf{R}$ & $\mathbf{S}$ & $\mathrm{CM}$ & $+0 \cdot I$ \\
\hline 3 & E. coli 53 & 100 & 120 & 150 & - & $\mathbf{S}$ & $\mathbf{R}$ & $\mathrm{CM}$ & $+0 . I$ \\
\hline 4 & & 100 & 125 & 60 & - & $\mathbf{S}$ & $\mathbf{R}$ & DEAE & $-I \cdot 0$ \\
\hline 5 & . & 100 & 0 & 350 & - & $\mathbf{R}$ & S & $\mathrm{CM}$ & +0.7 \\
\hline 6 & . & 100 & 160 & 15 & \pm & $\mathbf{R}$ & $\mathbf{S}$ & DEAE & -0.2 \\
\hline 7 & - & 100 & 180 & 0 & 二 & $\mathrm{R}$ & $\tilde{S}$ & $\mathrm{DEAE}$ & -0.6 \\
\hline 8 & . & 100 & 170 & 70 & - & $\mathrm{s}$ & $\mathbf{R}$ & DEAE & -0.6 \\
\hline
\end{tabular}

rate. Enzyme types 2, 3 and 5 are basic proteins since they are still positively charged even at $\mathrm{pH} 8 \cdot 5$, whereas all the other enzymes are anionic at this $\mathrm{pH}$ value. Of the three basic proteins, two are the cephalosporinases mentioned above. Enzyme types 3, 4 and 8 are all $p$ CMB-sensitive and cloxacillin-resistant, whereas all the other types have the opposite properties. Enzyme types I and 6 cross-react with anti-TEM serum to some extent, but none of the other enzymes are neutralized to any significant extent by this serum.

The wide range or properties found among the $\beta$-lactamases in enteric bacteria is, at first sight, a little surprising, particularly since all the strains examined here were first isolated because of a common property-resistance to ampicillin. However, minor variants of a basic penicillinase structure have been found within a single species in Bacillus cereus (Kogut, Pollock \& Tridgell, I956; Pollock, Torriani \& Tridgell, 
1956), Bacillus licheniformis (Pollock, 1964, 1965) and Staphylococcus aureus (Richmond, 1965) and indeed the enzymes from $B$. licheniformis and $S$. aureus have been shown to have a similar underlying amino acid sequence despite a different substrate profile, iso-electric point and amino acid composition (Ambler \& Meadway, 1969). Similarly, all the $\beta$-lactamases in the Gram-negative bacteria may well also share some basic sequence with minor variations in structure to account for the various substrate profiles and other properties encountered among the enzymes described here. The fact that at least six of the eight enzymes have a molecular weight in the range 15,000-20,000 and are sensitive to inhibition by iodine + KI solution (Datta \& Richmond, I966; Hennessey \& Richmond, I968; Jack \& Richmond, unpublished experiments) is at least consistent with this view. The low value for the molecular weight of the enzymes from Gram-negative strains suggests, however, that these enzymes may have relatively little in common with the lactamases from B. cereus, B. licheniformis and $S$. aureus, where the molecular weight of the single polypeptide chain of the penicillinases is about 30,000 (Citri \& Pollock, I966). If one has to guess any underlying molecular classes among the enzymes described in Table 5, the most likely would seem to be as follows. (I) A basic 'cephalosporinase' (types 2, 5; Table 5). (2) A general purpose $\beta$-lactamase sensitive to $p$ CMB but resistant to inhibition by cloxacillin and anti-TEM serum (Types 3, 4, 8; Table 5). (3) A general-purpose enzyme resistant to $p \mathrm{CMB}$ but sensitive to cloxacillin inhibition and to neutralization by antiTEM serum (types I, 6; Table 5).

It is difficult to identify with certainty the enzymes described here among the earlier reports of other workers, partly because few enzymes have been tested both against penicillins and cephalosporins and partly because certain tests (e.g. sensitivity to $p \mathrm{CMB}$ ) have only rarely been done. Apart from the enzymes from Enterobacter cloacae 2I4 and Aerobacter cloacae P99 mentioned earlier, the $\beta$-lactamase synthesized by strain 53 (Smith, 1963) is certainly of type 3 since the identical strain was included in the present survey. Similarly the enzyme synthesized by strain 418 of Klebsiella aerogenes (Hamilton-Miller, 1963) was included and is an example of type 6 enzyme. Sawai, Mitsuhashi \& Yamagishi (1969) surveyed a wide range of $\beta$-lactamases from Gram-negative species (excluding pseudomonads) using substrate profile and immunological cross-reaction to compare the enzymes and concluded that there were three distinct types of $\beta$-lactamase to be found: a 'cephalosporinase' found in Enterobacter freundii, Aerobacter aerogenes, Arizona (sic), Proteus morganii, $P$. rettgeri, $P$. inconstans and one strain of Serratia; a 'cephalosporinase which has a property of penicillinase' (presumably a mixed penicillinase/cephalosporinase profile) in $P$. vulgaris; and a penicillinase in $K$. pneumoniae, $P$. mirabilis and Escherichia coli. Of these the 'cephalosporinase' has reasonably uniform properties and may well be either type 2 or type 5 (or include both) in the classification shown in Table 5 . It seems unlikely, however, that the enzyme classified by the Japanese workers as 'penicillinase' represents a single type of molecule since its substrate profile is reported to range from I00: $1: 110$ in $E$. coli to 100:160:55 in K. pneumoniae and to I00: I40:5 in P. mirabilis. On the basis of these substrate profiles the enzymes found in $K$. pneumoniae and in $P$. mirabilis would correspond respectively to types 8 and 7 shown in Table 5 above, while the enzyme with profile IO0:I:IIo has not been detected by us. The Japanese workers also describe the properties of a 'penicillinase' synthesized by $E$. coli $\mathrm{w} 3630$ carrying an $\mathrm{R}$-factor $\left(\mathrm{R}_{\mathrm{GN14}}\right)$ (see also Egawa, 
Sawai \& Mitsuhashi, 1967). This enzyme has a very similar profile to TEM- $\beta$-lactamase and is therefore probably a representative of enzyme type I (Table 5). The fact that this enzyme is R-factor mediated in the Japanese strains and also commonly found in this state in the strains examined in Britain supports the view that TEM$\beta$-lactamase gene is often carried on an R-factor. However, this is not always the case since the TEM-lactamase component in strain 1758 (see p. 56) is not freely transferable whereas the second enzyme component in this strain is.

Although the properties of the eight types of $\beta$-lactamase described here go some way to account for the wide and variable range of activity of enteric bacteria against the penicillins and cephalosporins, two further factors are also important. The first is the ability of these strains to produce two distinct types of $\beta$-lactamase at once; and the second is that the level of expression of a given $\beta$-lactamase gene may vary greatly from strain to strain. Thus type I enzyme is synthesized to a level of only I unit/mg. dry wt in strain no. 35 (Table 2) but at more than roo times the rate in strain no. 44 (Table 2). Furthermore, when the gene in question is carried on an Rfactor, its level of expression can vary widely from recipient to recipient (Smith, I 969 ; G. W. Jack, unpublished observations). This combination of ability to synthesize one or more types of lactamase at a wide variety of rates ensures that any given enteric organism can have a profile ranging from that of an extreme penicillinase to that of an extreme cephalosporinase. Although the resistance of enteric strains to $\beta$-lactam antibiotics does not depend entirely on the type and quantity of enzyme synthesized, enzymic resistance is undoubtedly an important, perhaps the most important, factor in the resistance of the organisms. The wide range of profile that can be produced by varying the type and quantity of the various lactamases may well be the reason why no one penicillin or cephalosporin is fully effective against all enteric bacteria.

We are extremely grateful to Drs P. W. Muggleton, Cynthia O'Callaghan and their colleagues of Glaxo Research Ltd. for determining the cloxacillin sensitivity of all the strains used in these experiments, for providing certain strains for the studies, for a gift of cephaloridine and for many valuable discussions. We acknowledge generous gifts of benzylpenicillin from Glaxo Laboratories Ltd., and of ampicillin from Dr G. N. Rolinson of Beecham Research Ltd. The work was supported by the award of a Scholarship for Training in Research Methods to G.W.J. by the Medical Research Council, and of a grant-in-aid by the Royal Society to purchase a recording spectrophotometer (to M.H.R.).

\section{REFERENCES}

Alicino, J. F. (I946). Iodometric methods for the assay of penicillin preparations. Analytical Chemistry 18, 6r9.

Alicino, J. F. (I96I). Iodometric assay of natural and synthetic penicillins, 6-amino-penicillanic acid and cephalosporin C. Analytical Chemistry 33, 648.

Ambler, R. P. \& Meadway, J. (1969). Chemical structure of bacterial penicillinases. Nature 222, 24.

AYLIFFE, G. A. J. (1965). Cephalosporinase and penicillinase activity from Gram-negative bacteria Journal of General Microbiology 40, 119.

Citri, N. \& Pollock, M. R. (1966). The biochemistry and function of $\beta$-lactamase (penicillinase). Advances in Enzymology 28, 237.

Cowan, S. T. \& STEEL, K. J. (1966). Manual for the Identification of Medical Bacteria, p. 6r. Cambridge University Press. 
Datta, N. \& Kontomichalou, P. (1965). Penicillinase synthesis controlled by infectious R-factors in Enterobacteriaceae. Nature 208, 239.

DatTA, N. \& Richmond, M. H. (1966). The purification and properties of a penicillinase whose synthesis is mediated by an R-factor in Escherichia coli. Biochemical Journal 98, 204.

DESAI, P. \& GolDNER, M. (I968). Examination of various Gram-negative bacteria for $\beta$-lactamase activity. Canadian Journal of Microbiology 4r, 601.

Egawa, R., Sawal, T. \& Mrtsuhashi, S. (I967). Drug resistance of enteric bacteria. XII. Unique substrate specificity of penicillinase produced by R-factor. Japanese Journal of Microbiology rr, 173.

Evans, J., Galindo, E., Olarte, J. \& Falkow, S. (1968). $\beta$-lactamase of R-factors. Journal of Bacteriology 96, I44I.

FLEMING, P. C., GolDNER, M. \& GLASs, D. (1963). Observations of the nature, distribution and significance of cephalosporinase. Lancet i, 1399.

FreUND, J. \& Bonanto, M. (I94I). Formation after intravenous and subcutaneous injection of plain or alum diphtheric toxoid. Journal of Immunology 40, 437 .

Goldner, M., Glass, D. \& Fleming, P. C. (1968). Characteristics of Aerobacter $\beta$-lactamase. Canadian Journal of Microbiology 14, 139.

Gourevitch, A., Pursiano, T. A. \& LeIN, J. (I962). Inactivation of staphylococcal penicillinase by reaction with resistant penicillins. Nature 195, 496.

HAMILTON-Miller, J. M. T. (1963). Penicillinases from Klebsiella aerogenes. Biochemical Journal 87, 209.

Hamilton-MilleR, J. M. T. (1967). Hydrolysis of cephalosporins by $\beta$-lactamases from Gramnegative bacteria. Nature 214, 1333.

Hamilton-Miller, J. M. T., SMith, J. T. \& Knox, R. (1965). Interaction of cephaloridine with penicillinase-producing Gram-negative bacteria. Nature 208, 235.

Hamilton-MilleR, J. M. T., SMith, J. T. \& KNox, R. (1969). Bacterial resistance to penicillins and cephalosporins. Journal of Pharmacy and Pharmacology 2I, 337.

HeNNESSEY, T. D. (1967). Inducible $\beta$-lactamase in Enterobacter. Journal of General Microbiology 49, 277.

HenNessey, T. D. \& Richmond, M. H. (1968). The purification and some properties of a $\beta$-lactamase (cephalosporinase) synthesised by Enterobacter cloacae. Biochemical Journal rog, 409.

Kogut, M., Pollock, M. R. \& TRIDGell, E. (1956). Purification of penicillin-induced penicillinase of $B$. cereus NRRL 569: a comparison of its properties with those of a similarly purified penicillinase produced spontaneously by a constitutive mutant strain. Biochemical Journal 62, 39 I.

Lee, P. A. \& Rrchmond, M. H. (I969). A method for assessing the frequency of transfer of an Rfactor on solid media and for isolating cells of the donor type from a predominantly repressed culture. Journal of Bacteriology Iо0, I I $3 \mathrm{I}$.

LINDSTRÖm, E. B., Boman, H. G. \& SteEle, B. (1970). Resistance of Escherichia coli to penicillins. VI. Purification and characterization of the chromosomally mediated penicillinase present in amp A-containing strains. Journal of Bacteriology ror, 218-23r.

Menten, M. L., JUNGE, J. \& GREEN, M. H. (1944). A coupling histochemical azo-dye for alkaline phosphatase in the kidney. Journal of Biological Chemistry 153, 471.

Novick, R. P. (1962). Staphylococcal penicillinase and the new penicillins. Biochemical Journal 83, 229.

Novick, R. P. (1963). Analysis by transduction of mutations affecting the penicillinase formation in Staphylococcus aureus. Journal of General Microbiology 33, $12 \mathrm{I}$.

OfFord, R. E. (1969). Amino acids, peptides and proteins. In Data for Biochemical Research, 2nd ed., p. 534. Ed. by R. M. C. Dawson, D. C. Elliott, W. H. Elliott and K. M. Kones. Oxford University Press.

Perret, C. J. (1954). Iodometric assay of penicillinase. Nature 174, IOI 2.

Pollock, M. R. (1964). Stimulating and inhibiting antibodies for bacterial penicillinase. Immunology $7,707$.

Pollock, M. R. (1965). Purification and properties of penicillinases from two strains of Bacillus licheniformis: a chemical, physiochemical and physiological comparison. Biochemical Journal 94, 666 . 
Pollock, M. R. \& ToRriand, A.-M. (1953). Purification and characteristics (physico-chemico) of the penicillinase of B. cereus. Compte Rendu Hebdomadaire des Séances de l'Académie des Sciences, Paris 237, 276.

Pollock, M. R., Torriani, A.-M. \& Tridgell, E. (1956). Crystalline bacterial penicillinase. Biochemical Journal 62, 378.

Rrchmond, M. H. (1963). Purification and properties of the exopenicillinase from Staphylococcus aureus. Biochemical Journal 88, 452.

Richmond, M. H. (1965). Wild-type variants of exo-penicillinase from Staphylococcus aureus. Biochemical Journal 94, 584.

Sawai, T., Mrtsuhashi, S. \& Yamagishi, S. (I968). Drug resistance of enteric bacteria. XIV. Comparison of $\beta$-lactamases in Gram-negative rod bacteria resistant to $\alpha$-amino benzyl penicillin. Japanese Journal of Microbiology 12, 423.

SмIтH, J. T. (1963). Sulphydryl groups associated with penicillinase activity of Aerobacter cloacae. Nature 197, 900.

SмITH, J. T. (1969). R-factor gene expression in Gram-negative bacteria. Journal of General Microbiology 55, 109.

SMITHIES, O. (1955). Zone electrophoresis in starch gels: group variations in the serum proteins of normal human adults. Biochemical Journal 6r, 629. 